\title{
KEMAMPUAN BERFIKIR INTUITIF MAHASISWA CALON GURU DALAM PENYELESAIAN MASALAH MATEMATIKA
}

\author{
Srimuliati ${ }^{1}$, Wahyuni ${ }^{2}$ \\ ${ }^{1,2}$ Institut Agama Islam Negeri Langsa, jalan Meurandeh, Langsa 24411, Indonesia \\ Email: srimuliati@iainlangsa.ac.id \\ Email: wahyuni@iainlangsa.ac.id
}

\begin{abstract}
Abstrak
Penelitian ini bertujuan untuk mendeskripsikan kemampuan berfikir intuitif mahasiswa dalam penyelesaian masalah matematika. Sejalan dengan tujuan tersebut, penelitian ini menggunakan metode penelitian deskriptif kualitatif. Subyek penelitian sebanyak 3 mahasiswa masing-masing kemampuan tinggi, sedang dan rendah. Namun dalam prosesnya hanya dua mahasiswa yang dapat dianalisis jawabannya. Yaitu mahasiswa berkemampuan sedang dan tinggi. Metode pengambilan data menggunakan tes dan wawancara. Data dianalisis secara deskriptif melalui reduksi data, pemaparan data, dan penarikan kesimpulan. Hasil penelitian menunjukkan bahwa mahasiswa berkemampuan sedang (IM) menggunakan kemampuan berfikir intuitif antisipatori dalam menyelesaikan soal teori peluang nomor 2 , sedangkan soal nomor 1 dan 3 IM menyelesaikannya secara formal namun terdapat kesalahan. Mahasiswa dengan kemampuan tinggi (DC) berhasil menyelesaikan soal nomor 1 dan 2 secara formal dengan baik dan benar. Untuk soal nomor 3 DC menggunakan kemampuan berfikir intuitif antisipatori.
\end{abstract}

Kata kunci: Kemampuan Berfikir Intuitif, Kemampuan Matematika.

\section{Abstract}

This study aims to describe students' intuitive thinking skills in solving math problems. In line with these objectives, this study uses descriptive qualitative research methods. The research subjects were 3 students each with high, medium and low abilities. However, in the process only two students could have their answers analyzed. Namely students with medium and high abilities. Methods of data collection using tests and interviews. Data were analyzed descriptively through data reduction, data exposure, and drawing conclusions. The results showed that students with moderate ability (IM) used anticipatory intuitive thinking skills in solving probability theory questions number 2, while questions number 1 and 3 IM finished formally but there were errors. Students with high abilities (DC) successfully completed questions number 1 and 2 formally properly and correctly. For question number 3 DC uses anticipatory intuitive thinking skills.

Keywords : Intuitive Thinking Ability, Mathematical Ability.

\section{PENDAHULUAN}

Dalam mempelajari dan membelajarkan matematika baik di sekolah, perguruan tinggi atau di lembaga pendidikan tingkat manapun tidak akan terlepas dari masalah matematika. Dalam prosesnya, memecahkan masalah matematika ditempuh oleh guru ataupun dosen dengan beragam cara. Kadang kala dengan memberikan motivasi dan petunjuk agar mahasiswa berfikir terlebih dulu dan mencari penyelesaiannya, namun lebih sering memberi contoh bagaimana memecahkan suatu persoalan, dengan tidak memberi kesempatan kepada mahasiswa untuk menemukan sendiri jawabannya. Secara tidak langsung, membuat mahasiswa tergantung dengan dosen dan malas berfikir serta berusaha dan hal tersebut membuat mahasiswa menjadi kurang kreatif. Hal tersebut berakibat kepada lemahnya daya juang mahasiswa dan mahasiswa hanya mampu dan mau berusaha ketika telah diberikan caranya oleh Dosen. (Usodo, 2011).

Permasalahan di atas akan berimbas pada ketergantungan mahasiswa terhadap contoh dari Dosen dalam setiap menyelesaikan masalah. Misalnya, mahasiswa sama sekali tidak tahu apa yang harus dilakukan dengan persoalan yang diberikan jika permasalahan berbeda dari contoh atau 
mahasiswa telah mampu memulai, namun mengalami kemacetan di tengah penyelesaian persoalan matematika tersebut.

Dalam penyelesaian masalah, merencanakan strategi pemecahan dengan segera pada saat berhadapan dengan permasalahan, adakalanya mampu dilakukanoleh mahasiswa. Namun ada pula mahasiswa yang membutuhkan waktu jauh lebih lama untuk dapat menyelesaikannya. Hal ini menunjukkan bahwa kemampuan mahasiswa dalam menyelesaikan atau memecahkan permasalahan menjadi suatu fokus pembelajaran di semua jenjang pendidikan. Mengapa demikian, hal ini dikarenakan setiap kemampuan matematika mahasiswa pasti terikat dengan kemampuan penyelesaian masalah. Kemampuan memeriksa suatu informasi dalam suatu persoalan matematika, lalu menentukan cara untuk menyelesaikan permasalahan, dan memeriksa kembali jawaban agar tidak terjadi kesalahan, hanya bisa dilatihkan dengan sesering mungkin memecahkan masalah matematika.

Nazariah, dkk (2017) mengatakan bahwamahasiswa akan memperoleh cara-cara berfikir di dalam situasi yang tidak biasa salah satunya dengan mempelajari pemecahan masalah di dalam matematika. Maksudnya, mahasiswa akan mampu jika dihadapkan dengan masalah matematika ketika berada di ruang kelas matematika. Ataupun dalam kehidupan, mahasiswa akan mampu menemukan solusi dalam setiap persoalan.

Muniri (2018) menambahkan, kemampuan mahasiswa dalammemahami serta menemukan cara untukmemecahkan permasalahan matematika secara tepat, selain dipengaruhi oleh aktifitas kognitif juga dipengaruhioleh aktivias mental. Aktifitas mental yang dimaksud, ditopang oleh kemampuan berpikir yang mampu memunculkan ide secara spontan. Sa'o (2016) menyebutkan kemampuan berfiikir spontan tersebut dikenal dengan berpikir intutif. Berfikir intuitif juga dipengaruhi oleh perasaan serta keyakinan yangkuat dari sipemikir dalam usahanya memecahkan permasalahan, dalam hal ini permasalahan matematika.

Dari pengetahuan matematika, Usodo membagi kognisi menjadi 2 bagian yaitu kognisi formal dan kognisi intuitif.Disebut kognisi formal jika merujukpada kognisi yang dikontrol oleh logika matematika. Pengetahuan matematika dipahami secara ketat oleh kognisi formal. Tapi dalam kognisi formal setiap langkah berpikir dalam bermatematika tidak dipaparkan dengan jelas (Usodo, 2011). Berbeda dengan kognisi formal, seperti disebut sebelumnya bahwa ada kognisi intuitif yang digunakan dalam mengoperasikan kegiatan matematika. Seperti ditegaskan oleh Fischbein (dalam Mohammad \& Dede , 2019), ia menyatakan bahwa intuisi merupakan sebuah jenis kognisi dan bukan sebuah metode.

Peneliti dalam beberapa kesempatan mengajar di kelas, awalnya selalu mengupayakan mahasiswa menemukan solusi sendiri terhadap persoalan. Namun sering berakhir dengan kebuntuan dimana akhirnya mahasiswa hanya meniru contoh dari yang sudah diajarkan. Sehingga, lanjut Budi, melihat kenyataan tersebut menjadikan mahasiswa tidak kreatif dalam usahanya menyelesaikan sebuah persoalan matematika. Akibatnya mahasiswa bisa menyelesaikan persoalan matematika apabila telah diberikan caranya oleh Dosen (Muniri, 2018; Usodo, 2011). Kondisi ini membuat mahasiswa jika dihadapkan pada kesulitan, mahasiswa tidak akan mampu melaluinya. Contohnya jika mahasiswa secara tiba tiba diberikan sebuah persoalan matematika. Mahasiswa tidak tahu apa yang harus diperbuat dengan persoalan tersebut, ia kebingungan harus memulai dari mana atau menuliskan informasi, atau mahasiswa sudah mampu menuliskan informasi lalu mengalami kemacetan di tengah penyelesaian, meski sebenarnya ia memiliki bekal yang cukup untuk menyelesaikan permasalahan tersebut, namun akhirnya ia lebih memilih menyerah. Kenyataan tersebut menyadarkan akan pentingnya melihat cara mahasiswa menemukan penyelesaian masalah melalui beragam cara (Mohammad \& Dede, 2019; Sa'o, 2016; Sukmana, 2011; Tri, 2018). Tidak menuntut mahasiswa mengerjakan langkah perlangkah. Dalam beberapa kesempatan materi matematika, memungkinkan untuk melihat hal tersebut. Kognisi intuitif mengambil peran tersebut. 
Fischbein (dalam Sukmana, 2011; Usodo, 2012) menyajikan karakteristik umum kognisi intuitif dalam matematika. Karakteristik intuisi tersebut yaitu: (1) kognisi langsung, kognisi selfevident, keduanya merupakan kognisi yang diterima sebagai feeling individual dimana tidak diperlukan pengecekan dan pembuktian lanjutan., (2) kepastian intrinsik (intrinsic certainty) yaitu intuisi atau suatu perasaan akan kepastian intrinsik (merasa yakin dengan hal yang hanya dipahami oleh individu)., (3) pemaksaan (coerciveness) yaitu intuisi mempunyai sifat menggiring maksudnya, jika seorang individu meyakini dengan kuat akan suatu hal maka ia akan membawa lawan (interpretasi alternatif) ke arah yang diyakininya tersebut. Ini berarti individu coerciveness akan menolak pendapat di luar dirinya yang akan mengkontradiksi intuisinya., (4) extrapolativeness yaitu kemampuan untuk melihat peluang di balik suatu keyakinan yang kuat. Dapat dikatakan bahwa individu tersebut mampu meramal dengan suatu yang hanya individu tersebut yang mampu menjelaskan., dan (5) globality atau keseluruhan yaitu kognisi global yang berlawanan dengan kognisi yang diperoleh secara logis, berurutan dan secara analitis.

Berdasarkan hal tersebut, kelima karakteristik di atas terkonfirmasi sebagai karakteristik intuitif afirmatori yaitu karakteristik intuisi yang berupa solusi, pernyataan, interpretasi, dan representasi yang secara individual dapat diterima tanpa membutuhkan pembuktian lanjutan. Karakteristk lainnya yaitu karakteristik intuisi antisipatori dan intuisi konklusif. Karakteristik antisipatori merupakan karakteristik intuisi yang berhubungan dengan pemecahkan masalah. Karakteristik intuisi antisipatori bercirikan : (1) intuisi muncul selama dengan usaha yang keras melakukan penyelesaian terhadap masalah artinya individu terus berupaya tanpa henti untuk menemukan penyelesaian dari permasalahan, (2) intuisi tersebut menyajikan karakter global, (3) intuisi individu bertentangan dengan dugaan pada umumnya, dan intuisi ini berasosiasi dengan feeling dari keyakinan, meskipun bukti belum ditemukan. Berikutnya, intuisi konklusif.Merupakan usaha membuat konklusi (simpulan) secara umum inti dari suatu penyelesaian masalah.

Fischbein (Muniri, 2018; Sa'o, 2016; Usodo, 2011) telah menyatakan bahwa dalam suatu kondisi, di mana mahasiswa dihadapkan pada penyelesaian matematika, adakalanya mahasiswa merasa yakin terhadap kemampuannya. Akan tetapi hanya sedikit mahasiswa yang berhasil dalam menggunakan aktivitas pemikiran formal dalam hal ini kognisi formal. Disisi lain, terdapat mahasiswa yang dengan kemampuan kreatifnya mampu memecahkan masalah matematika dengan tepat, namun tidak menggunakan aktivitas pemikiran formal dimana langkah perlangkah atau tahapan penyelesaian menjadi penting.

Hal tersebut semakin menguatkan bahwa terdapat aktivitas pemikiran yang berbeda dengan aktivitas pemikiran formal dalam melakukan kegiatan pemecahan masalah. Pentingnya intuisi bagi mahasiswa salah satunya dapat membantu memperoleh penyelesaian yang kreatif, bukan langkah perlangkah. Namun, mahasiswa hanya dapat memperoleh penyelesaian yang benar,jika intuisi dengan konsep matematika secara formal dapat seiring sejalan.Berdasarkan hal tersebut,peneliti tertarik untuk mengetahui kognisi intuitif yang dimiliki mahasiswa dalam menyelesaikan permasalahan matematika.

\section{METODE PENELITIAN}

Penelitian ini dilakukan di IAIN Langsa pada mahasiswa calon guru matematika. Dilaksanakan pada semester genap 2019/2020 dan melibatkan mahasiswa semester IV yang mengambil mata kuliah teori peluang. Adapun instrumen dalam penelitian ini menggunakan tes dan wawancara. Tes yang digunakan yaitu tes soal materi teori peluang yang diambil langsung dari dosen pengampu mata kuliah teori peluang. Instrument tes melibatkan indikator teori peluang yang tercantum dalam silabus mata kuliah yaitu mahasiswa mampu memecahkan peluang kejadian sederhana, bersyarat, saling asing dan saling bebas.

Dengan jenis penelitian kualitatif, peneliti menggunakan instrumen tes teori peluang untuk menganalisis kemampuan berfikir intuitif mahasiswa yang muncul selama menyelesaikan persoalan. 
Adapun indikator kemampuan berfikir intuitif yang akan dilihat mengacu kepada karakteristik berfikir intuitif itu sendiri, seperti disebutkan oleh Fischbein (Muniri, 2018; Sa'o, 2016; Usodo, 2011), (1) karakteristik afirmatori yaitu karakteristik intuisi yang berupa solusi, pernyataan, interpretasi, dan representasi yang secara individual dapat diterima tanpa membutuhkan pembuktian lanjutan. (2) karakteristik intuisi antisipatori dan intuisi konklusif. Karakteristik antisipatori merupakan karakteristik intuisi yang berhubungan dengan pemecahkan masalah. Karakteristik intuisi antisipatori bercirikan : (a) intuisi muncul selama dengan usaha yang keras melakukan penyelesaian terhadap masalah artinya individu terus berupaya tanpa henti untuk menemukan penyelesaian dari permasalahan, (b) intuisi tersebut menyajikan karakter global, (c) intuisi individu bertentangan dengan dugaan pada umumnya, dan intuisi ini berasosiasi dengan feeling dari keyakinan, meskipun bukti belum ditemukan. (3) karakteristk intuisi konklusif merupakan usaha membuat konklusi (simpulan) secara umum inti dari suatu penyelesaian masalah.

Data diolah secara deskriptif untuk menggambarkan karakteristik yang muncul selama mahasiswa menyelesaikan persoalan. Kemampuan berfikir mahasiswa lalu dianalisis sesuai dengan kognisi intuitif yang digunakan. Peneliti memilih 3 mahasiswa sesuai tingkat kemampuan matematika yaitu kemampuan tinggi, sedang dan rendah untuk menggambarkan cara ketiganya memecahkan persoalan matematika dengan menggunakan kognisi intuitif. Soal teori peluang diberikan kepada seluruh mahasiswa semester IV yang mengambil mata kuliah tersebut. Dalam prosesnya, sesuai dengan tahapan penelitian, peneliti memilah mahasiswa sesuai kategori yaitu mahasiswa berkemampuan tinggi, sedang dan rendah. Namun, hasil tes menunjukkan bahwa rata rata mahasiswa berada dalam kategori sedang dan rendah. Hal ini disebabkan tidak tampak adanya mahasiswa berkemampuan tinggi dan keterbatasan tim peneliti dalam menganalisis seluruh mahasiswa. Sehingga dipilihlah 2 mahasiswa untuk dianalisis jawabannya.

\section{HASIL PENELITIANDAN PEMBAHASAN}

\section{Analisis Soal 1 pada Mahasiswa Subjek 1(IM)}

Berikut ini merupakan deskripsi hasil jawaban mahasiswa terhadap tes yang dilakukan untuk soal "Dua dadu dilantunkan, berapakah peluang mendapatkan jumlah lima dan paling banyak jumlahnya empat.":

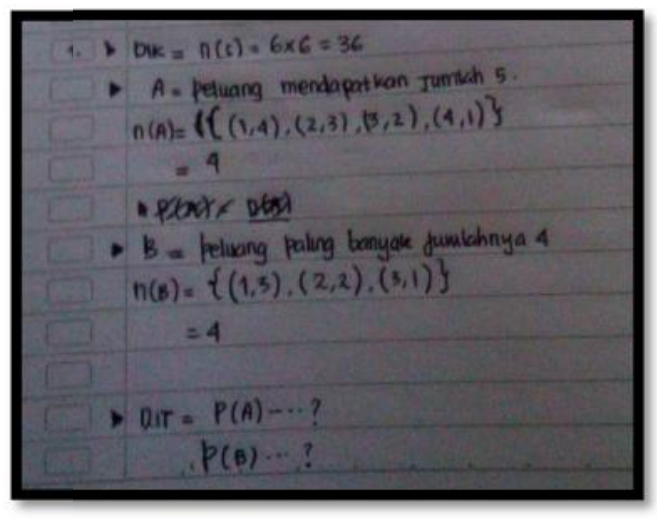

Gambar Hasil Tes Soal No. 1 IM (Subjek 1) 
Hasil tes IM menunjukkan bahwa IM mampu membuat tahapan penyelesaian namun IM belum mampu mencerna soal dengan baik sehingga belum tepat dalam menjabarkan apa yang diketahui dari ruang sampel "paling banyak jumlahnya 4".

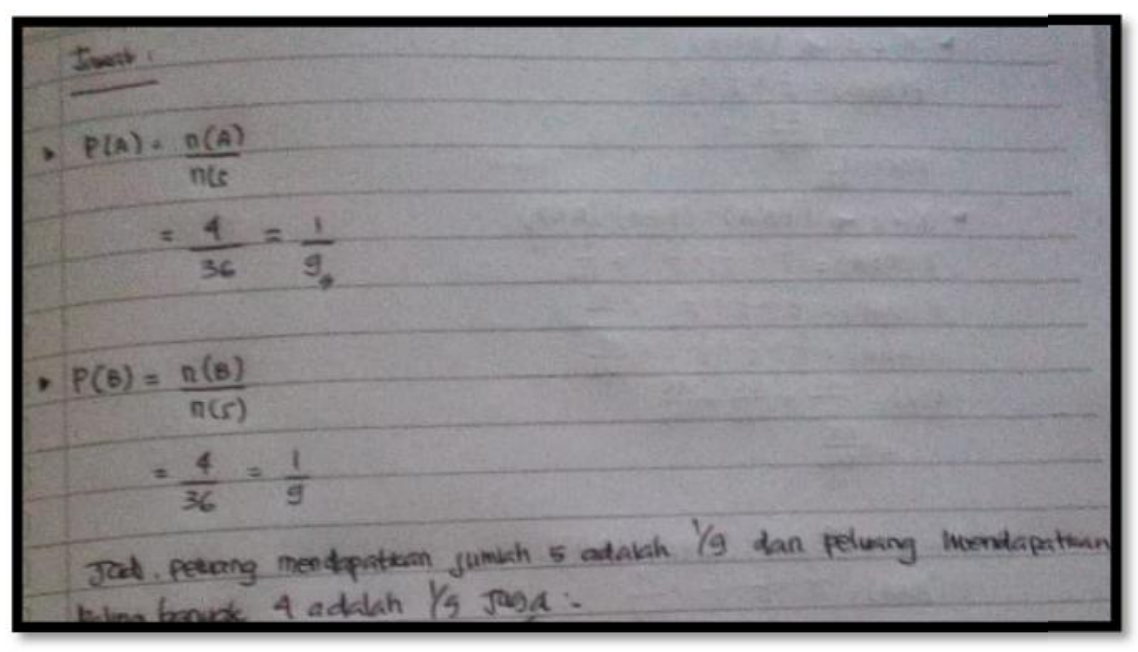

\section{Gambar Lanjutan Hasil Tes Soal No. 1 IM}

Dapat dilihat bahwa hasil jawaban juga tidak tepat. Hal ini menunjukkan bahwa IM keliru dalam menerjemahkan soal cerita terkait dadu. Dari hasil wawancara juga diketahui bahwa IM tidak teliti dan tidak memahami maksud soal serta terburu buru dalam membaca soal sehingga melewatkan kata kata yang menjadi kode dalam penyelesaian soal yaitu "paling banyak" yang bermakna $\leq 4$. Lalu kemampuan intuitif apa yang muncul dari cara kerja IM dalam menyelesaikan soal? Jika dilihat dari cara kerja IM dalam menyelesaikan soal No. 1 dapat diketahui bahwa IM menyelesaikan secara langsung menggunakan apa yang telah dipahaminya sesuai dengan apa yang dipelajarinya. Sehingga dapat dikatakan bahwa IM tidak menggunakan proses berfikir kreatif dengan memunculkan cara baru dalam memecahkan soal. Namun IM tetap melalui proses bernalar sebagaimana mestinya dalam menyelesaikan soal.

\section{c.2. Analisis Soal 2 pada Mahasiswa Subjek 1(IM)}

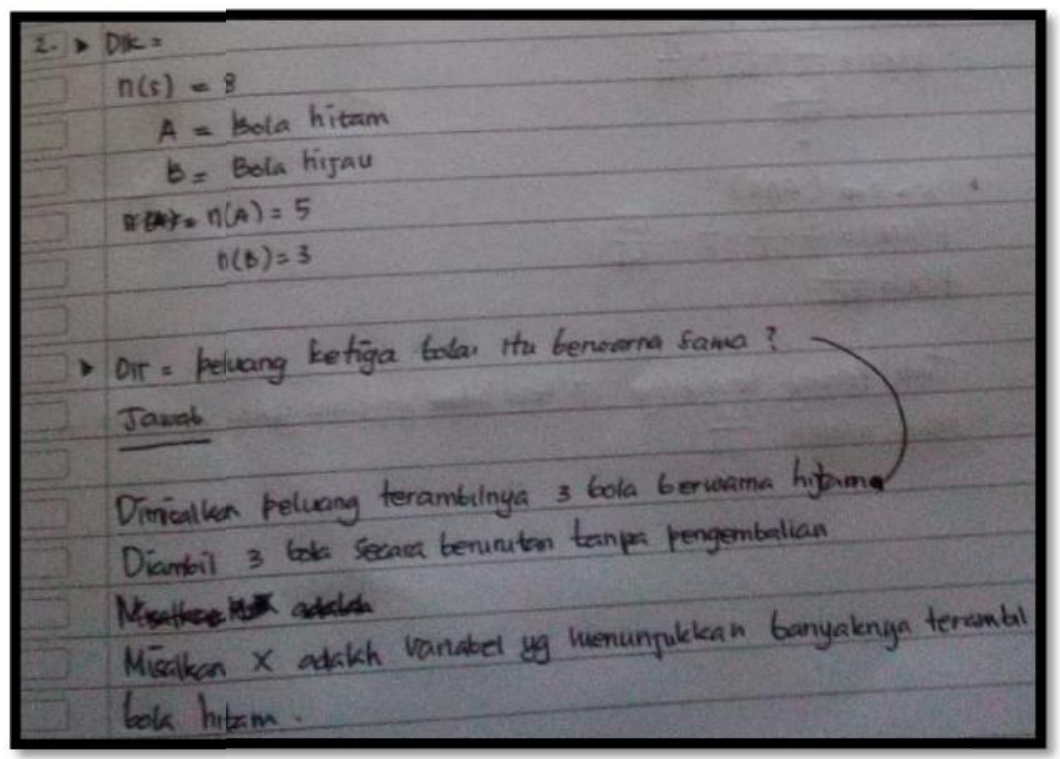

Gambar Hasil Tes Soal No. 2 IM

Jawaban IM untuk soal nomor 2 menunjukkan bahwa IM mampu menyebutkan informasi dari soal. IM menunjukkan bahwa ia mampu merencanakan penyelesaian. IM melakukan proses berfikir dimana IM menarik semua informasi yang dimiliknya untuk menjabarkan segala informasi yang bisa 
diperoleh dari soal. Dengan demikian IM dapat membuat rencana penyelesaian. Dari wawancara juga diperoleh bahwa IM melakukan kehati-hatian dalam membaca setiap informasi agar memudahkan dalam membuat rencana penyelesaian.

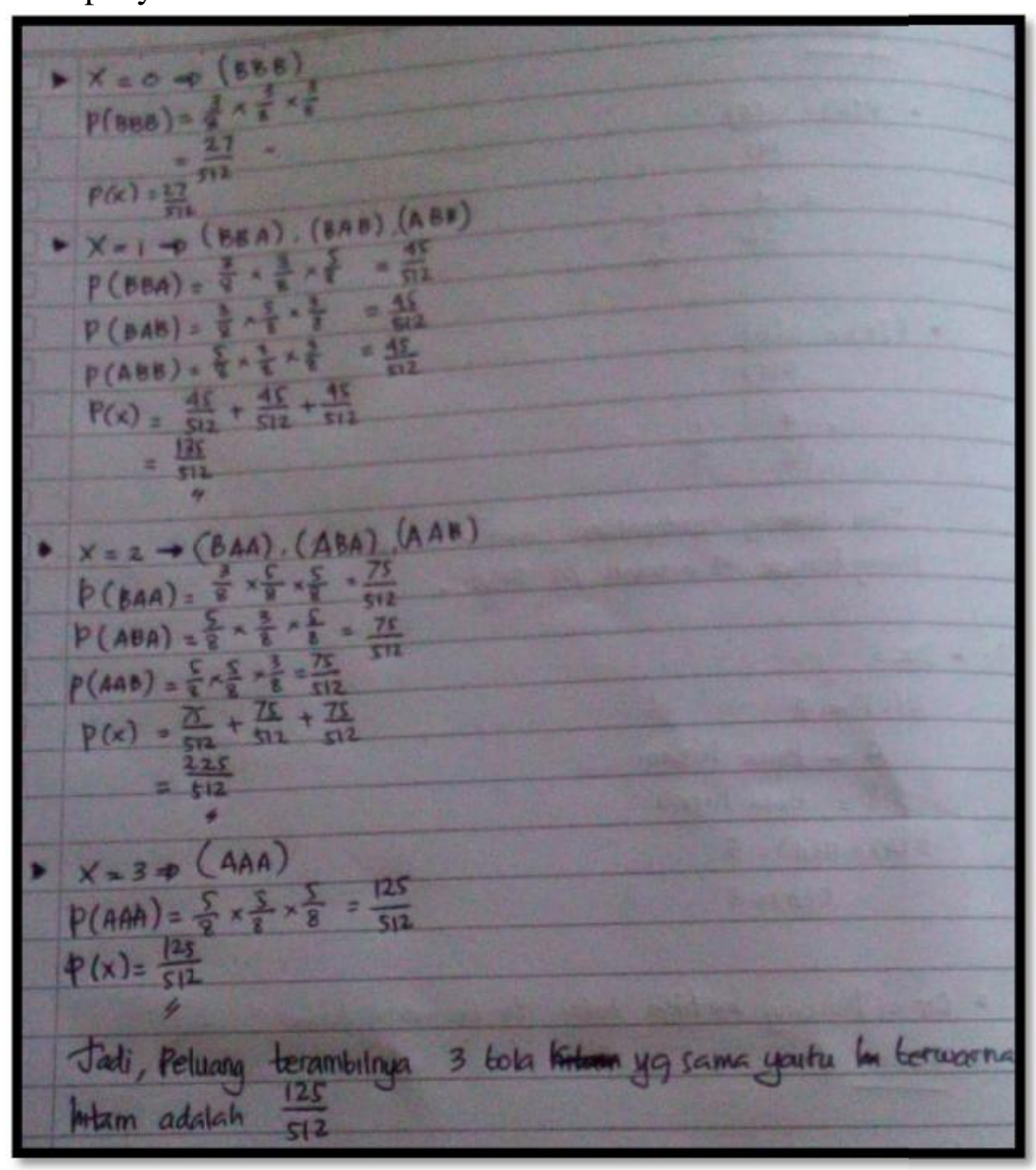

Gambar Lanjutan Hasil Tes Soal No. 2 IM

Jawaban soal nomor 2 yang dilakukan IM menunjukkan bahwa IM melakukan hal yang tidak umum dilakukan oleh mahasiswa dalam menyelesaikan persoalan dari teori peluang. IM mampu menalar dengan sangat baik dan menunjukkan proses berfikirnya yang lain dari kebanyakan mahasiswa. Ini menunjukkan bahwa IM memiliki kreatifitas dalam mengolah jawaban dengan menggunakan proses penalaran yang sederhana namun kaya akan informasi. Terjadi proses berfikir intuitif di sini. Yaitu IM mampu memunculkan ide sederhana yang dipahaminya selama proses belajar seperti mampu membuat titik sampel dari soal yang umumnya dilupakan dalam pengerjaan soal seperti di atas, Fischbein (Muniri, 2018; Sa'o, 2016; Usodo, 2011) menyebutnya dalam karakteristik antisipatori yaitu bercirikan : (1) intuisi muncul selama dengan usaha yang keras melakukan penyelesaian terhadap masalah artinya individu terus berupaya tanpa henti untuk menemukan penyelesaian dari permasalahan.. Walaupun secara algoritma penyelesaian berbeda dari biasanya yang diajarkan, namun proses kreatif IM ini dapat disebut sebagai cara berfikir intuitif dalam memberikan bukti penyelesaian secara masuk akal.

\section{c.3. Analisis Soal 3 pada Mahasiswa Subjek 1(IM)}

Untuk soal nomor 3, IM mengalami proses berfikir yang lebih sederhana dengan menggunakan algoritma yang cenderung umum dipakai dalam penyelesaian masalah seperti berikut: 


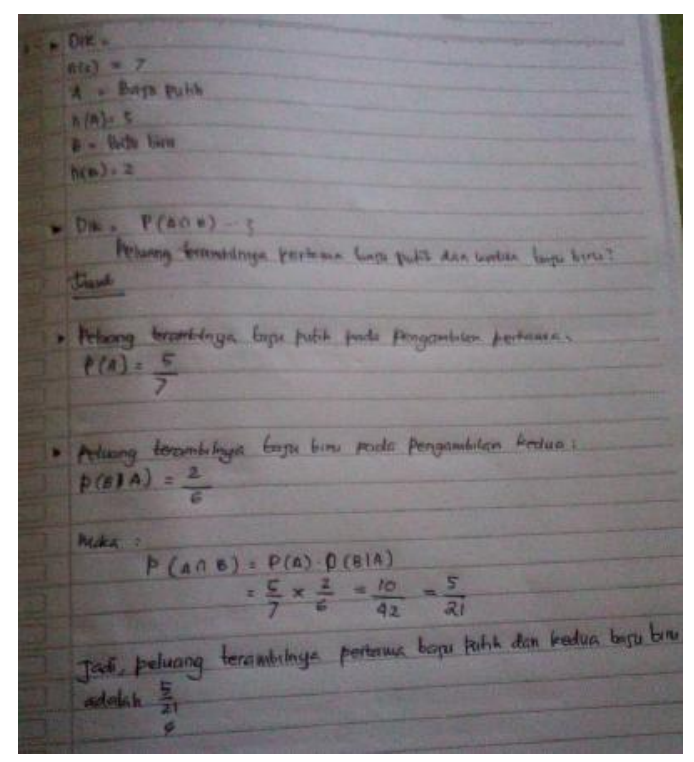

Gambar Hasil Tes Soal No. 3 IM

Jawaban nomor 3 dari IM menunjukkan bahwa setelah melalui proses berfikir yang panjang pada soal nomor 2, IM menemukan pola tersendiri dalam menyelesaikan soal. IM tetap tidak melupakan tahapan menggali informasi namun IM masih keliru dalam mengolah informasi yang diberikan. IM kurang teliti dalam membaca soal dan ini dibenarkan malalui hasil wawancara. IM tidak memaknai soal sehingga salah dalam menuliskan informasi. Ada 3 baju putih namun IM menuliskan 2. Lalu IM keliru dan terburu-buru dalam menentukan penyelesaian. Sehingga berakibat terhadap jawaban yang salah.

Pada jawaban soal nomor 1 dan 3, IM melakukan hal yang umum dilakukan dalam menyelesaikan persoalan teori peluang walaupun kurang tepat. Namun untuk jawaban soal nomor 2, IM menggunakan penyelesaian matematika yang berbeda dari keumuman mahasiswa. Menurut definisi dari intuisi antisipatori, IM telah menemukan suatu pemikiran secara tiba tiba dalam usahanya memecahkan masalah. Seperti yang terlihat dalam jawaban IM. Sehingga dapat disimpulkan bahwa IM menggunakan intuisi antisipatori dalam usahanya memecahkan masalah teori peluang, Fischbein (Muniri, 2018; Sa'o, 2016; Usodo, 2011). 


\section{c.4. Analisis Soal 1 pada Mahasiswa Subjek 2 (DC)}

Jawaban mahasiswa DC terkait soal nomor 1 dapat dijelaskan sebagai berikut :
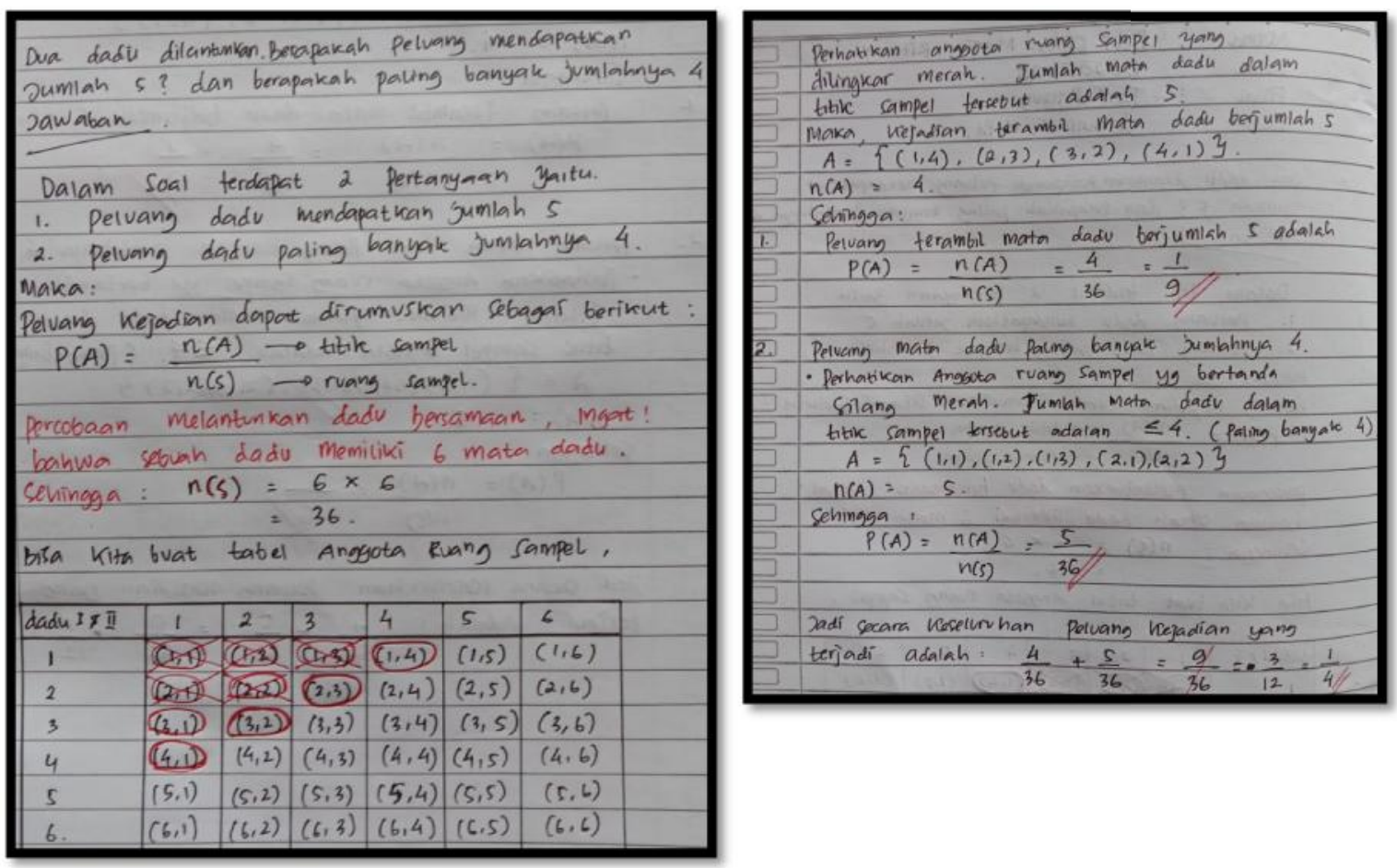

\section{Gambar Hasil Soal No. 1 Mahasiswa DC}

Gambar di atas menunjukkan bahwa mahasiswa DC menjabarkan dengan jelas dan terstuktur pemikirannya dalam menjawab persoalan nomor 1. DC mampu memahami dengan baik informasi dari soal dan mampu merencanakan penyelesaiannya. Serta dengan kejeliannya dalam membaca 'kode' soal, DC mampu menuliskan dengan baik maksud soal. Namun DC masih kurang teliti dalam merefleksi jawaban sehingga masih ditemukan kesalahan. Yaitu dalam menuiskan ruang sampel dari jumlah dadu $\leq 4$. DC hanya menuliskan 5 anggota yaitu $\{(1,1),(1,2),(2,1),(1,3)$ dan $(2,2)\}$ sedangnya ada satu anggota lainnya yang terlupakan yaitu $(3,1)$. Sehingga berakibat kepada salahnya jawaban akhir. Dalam bermatematika, ketelitian dan kejelian mutlak diperlukan guna menghindari kesalahan. Jawaban DC di atas masih dalam bentuk formal jawaban teori peluang pada umumnya. Namun dalam level yang berbeda, karena DC mampu menuliskan dengan baik, lengkap dan terstruktur sehingga mudah dipahami bagi yang tidak mengerti matematika. 


\section{c.5. Analisis Soal 2 pada Mahasiswa Subjek 2 (DC)}
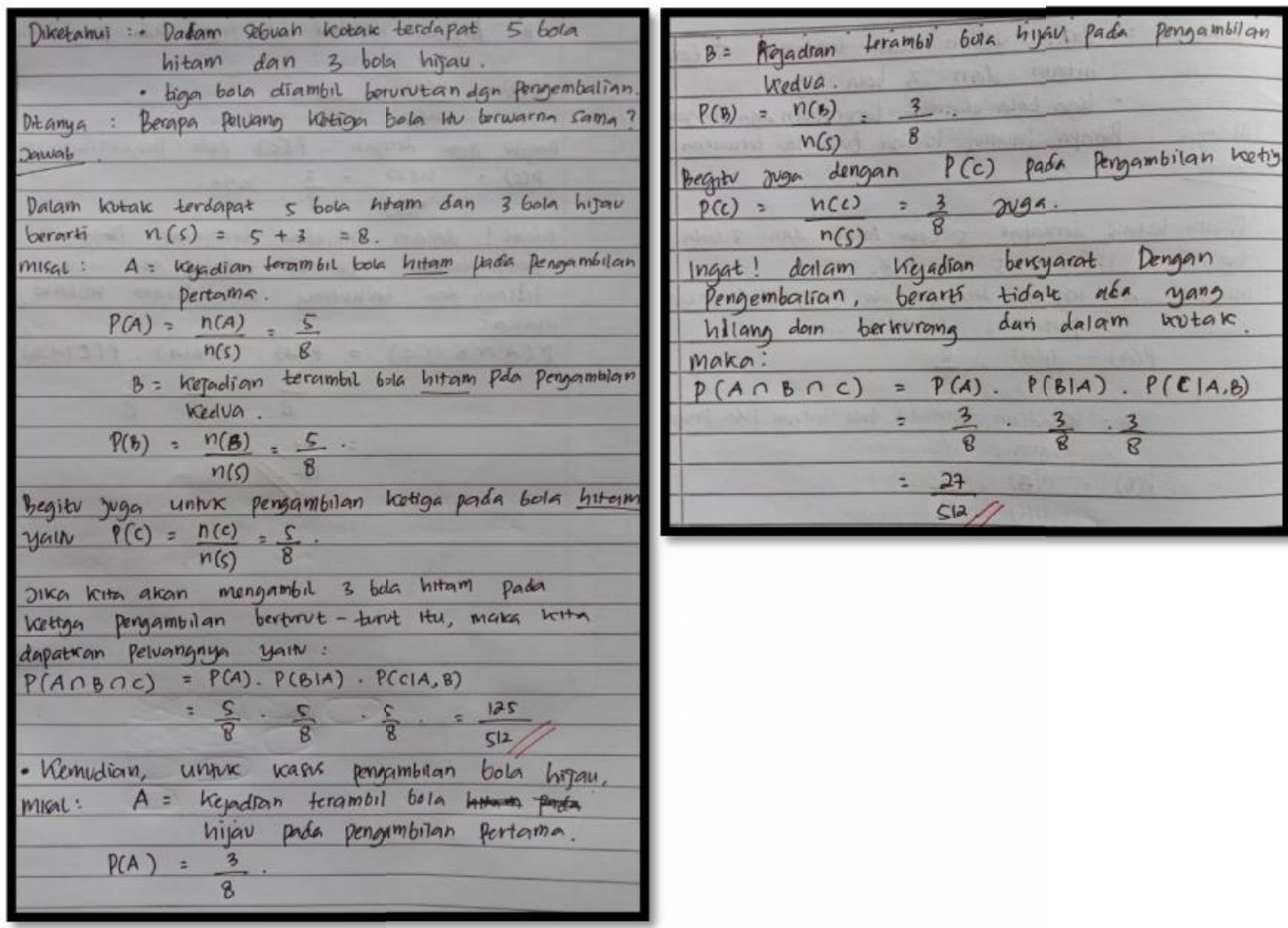

Gambar Hasil Tes Soal No. 2 Mahasiswa DC

Jawaban DC pada gambar di atas merupakan jawaban formal dari teori peluang. DC berhasil mengingat semua informasi terkait soal dan menggunakannya dalam memecahkan persoalan. DC mampu merunut semua informasi dan merencanakan dengan baik penyelesaian sehingga dengan sedikit ketelitian DC mampu menemukan solusi dari persoalan. Proses berfikir yang digunakan DC hanyalah penalaran biasa. Namun tidak semua mahasiswa juga mampu menyelesaikannya. Walaupun tidak ada proses berfikir intuitif di sana, DC mampu mengingat semua materi terkait soal nomor 2 dan mengetahui penyelesaian formal / rumus matematika dalam teori peluang. 


\section{c.6. Analisis Soal 3 pada Mahasiswa Subjek 2 (DC)}

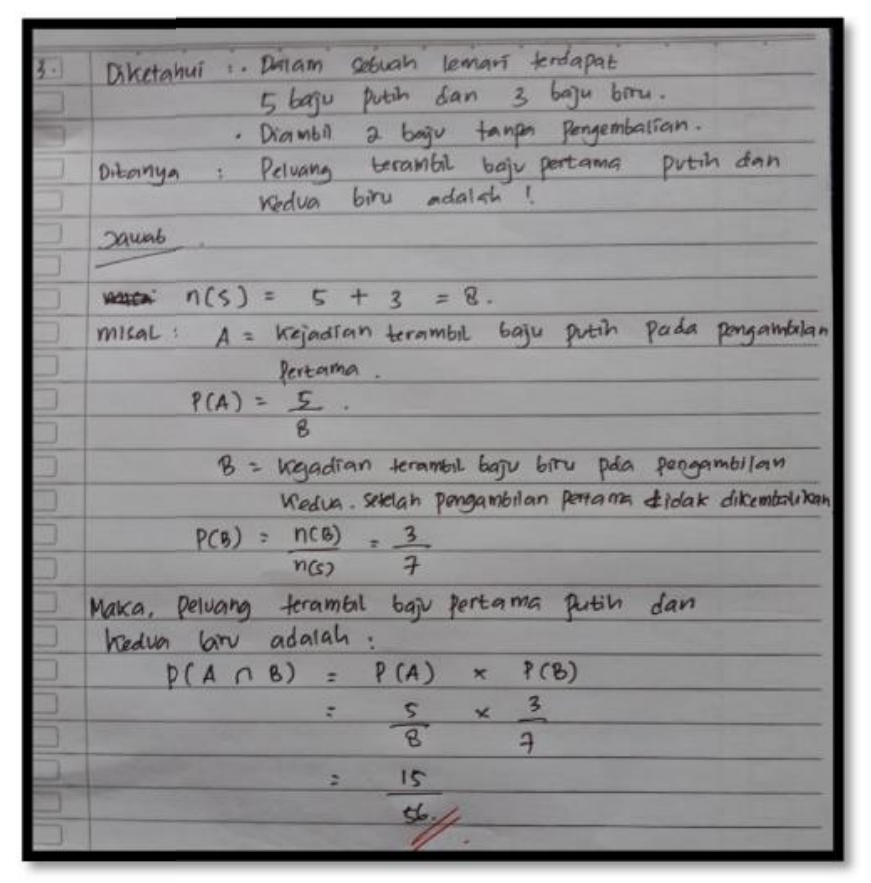

Gambar Hasil Tes Soal No. 3 Mahasiswa DC (Subjek 2)

Untuk soal nomor 3, DC mampu menuliskan informasi dari soal yang diberikan. Terlihat dari DC menuliskan diketahui dan ditanya, itu menunjukkan bahwa DC memahami maksud soal. Dengan pengetahun itu DC mampu merencanakan penyelesaiannya. DC memilih untuk menuliskan jumlah ruang sampel dengan cara sederhana. Namun DC mampu memisahkan informasi secara tertib dan itu memudahkan DC dalam melaksanakan rencana penyelesaian. Secara logika, pemilihan DC terhadap rumus (x) tidak tertulis dengan baik. Memilih mengalikan kedua sampel dan bukannya cara yang lain tidak tertulis dan dijelaskan dengan baik. Namun DC memahami alasan pemilihan operasi perkalian tersebut. Dari hasil wawancara diketahui bahwa DC memahami apa yang dilakukannya. Awalnya DC bingung memilih menggunakan rumus yang mana, lalu dengan usahanya secara tiba tiba DC sampai pada penalaran bahwa kejadian pemilih baju dengan beda warna adalah kejadian yang saling lepas dan tidak saling berhubungan. Pemikiran tersebut dapat dikatakan bahwa DC telah melakukan proses berfikir intuitif antisipatori dimana DC dengan usaha kerasnya dalam memecahkan masalah dan secara tiba tiba sampai pada pemahaman tertentu.

\section{Pembahasan}

Dari hasil olah data terhadap 2 mahasiswa di atas terhadap penyelesaian masalah teori peluang, diperoleh bahwa dalam proses menemukan jawaban tersebut mahasiswa masih cenderung menyelesaikan dengan langkah perlangkah. Hal itu menunjukkan bahwa mahasiswa masih menggunakan kognisi formal dan sudah terlatih dengan hal tersebut. Namun dalam proses menemukan penyelesaian, mahasiswa telah melakukan proses menalar, memunculkan intuisi seperti membuktian secara individual dan feeling dari keyakinan, serta muncul pemikiran secara tiba tiba karena usahanya dalam memecahkan masalah. Maksudnya mahasiswa mampu menuliskan informasi dan mengolah jawaban dengan menggunakan logika matematika yang tidak umum dipakai oleh mahasiswa selama teori peluang diajarkan. Hal ini menunjukkan bahwa ada kognisi intuitif yang digunakan yaitu intuitif antisipatori. Seperti disebutkan oleh Fischbein (Usodo, 2012) dimana salah satu ciri dari intuitif antisipatori yaitu mahasiswa memperoleh jawaban setelah berusaha keras mengolah informasi dan mengujicoba persoalan dalam berbagai cara. 
Penjelasan tersebut berlaku untuk kedua subjek. Namun pada penyelesaian soal nomor 1 dan 3, subjek (IM) mahasiswa berkemampuan sedang yang terpilih, melakukan proses yang umum dilakukan dalam menyelesaikan persoalan teori peluang. Namun menghasilkan jawaban yang kurang tepat. Proses kognisi formal yang dilakukan IM tidak lengkap dan IM melewatkan "kode"dalam soal yang menjadi kunci dari penyelesaian soal. IM kurang teliti dalam membaca soal. Dan pada soal nomor 2 IM mampu menunjukkan kemampuan berfikirnya secara intuitif.

Berbeda dengan IM, DC subjek berkemampuan tinggi, menyelesaikan soal nomor 1 dan 2 secara tepat dengan menggunakan kognisi formal. Ia mampu menuliskan informasi, merumusakan permasalahan dan menyesaikan dengan kedua soal tersebut. Pada soal nomor 3 DC baru terlihat proses berfikir intuitif antisipatori dimana secara tertulis terlihat bahwa DC seperti mengikuti penulisan formal dalam penyelesaian teori peluang. Namun melalui wawancara terungkap bahwa awalnya DC kebingungan menulis rumusan penyelesaiannya, setelah berfikir dan mencoba coba akhirnya DC menemukan alasan yang tepat dalam pemilihan rumus.

Oleh Fischbein (Muniri, 2018; Sa'o, 2016; Usodo, 2011) telah disebutkan bahwa dalam suatu kondisi, di mana mahasiswa dihadapkan pada penyelesaian matematika, adakalanya mahasiswa merasa yakin terhadap kemampuannya. Ini berlaku pada mahasiswa DC, ia mampu menuliskan dan menyelesaikan dengan baik persoalan yang diberikan. Disisi lain, terdapat mahasiswa yang dengan kemampuan kreatifnya mampu memecahkan masalah matematika dengan tepat, namun tidak menggunakan aktivitas pemikiran formal. Ini yang dilakukan oleh IM dalam menyelesaikan permasalah teori peluang nomor 2 .

Hal tersebut menunjukkan bahwa ada aktifitas mental lainnya seperti yang telah disebutkan sebelumnya selain dari proses berfikir formal, yaitu berfikir intuitif. Berfikir intuitif atau disebut juga kognisi intuitif adalah suatu hal yang tidak bisa diabaikan dalam proses penyelesaian matematika. Dosen tidak bisa mengabaikan bahwa adakalanya mahasiswa tidak menjawab seperti apa yang dicontohkan, namun mahasiswa memiliki cara penyelesaiannya sendiri yang dapat dipertanggungjawabkan (Sukmana, 2011; Susilawati et al., 2017). Hal demikian baik demi perkembangan keilmuan dan menumbuhkan kepercayaan diri dan kreatifitas mahasiswa dalam menyelesaikan persoalan matematika (Ermawan, 2018; Sa'o, 2016).

\section{KESIMPULAN}

Penelitian ini memberikan kesimpulan bahwa mahasiswa dengan kemampuan sedang (IM) dan kemampuan tinggi (DC) memiliki kesamaan sekaligus perbedaan dalam menyelesaikan persoalan matematika teori peluang. Mahasiswa IM menyelesaikan dua soal menggunakan kognisi formal namun masih ada kesalahan dan menyelesaikan soal nomor 2 dengan menggunakan kognisi intuitif yaitu intuitif antisipatori. Mahasiswa DC mampu menggunakan kedua kognisi dengan baik dan benar. Kognisi intuitif yang digunakan sama dengan IM yaitu intuitif antisipatori.

\section{REFERENCES}

Fauzi, Galuh dan Ismail. (2018). Analisis Penggunaan Intuisi pada Pemecahan Masalah Matematika Siswa SMP Berdasarkan Kemampuan Matematika Siswa. Mathedunesa Jurnal Ilmiah Pendidikan Matematika E-ISSN 2301-9085, 7 (3), 2018. 644-650.

Mohamad Gilar Jatisunda, Dede Salim Nahdi. (2019). Peran Matematical Intuition dalam Pembelajaran Matematika. Jurnal Matematika Ilmiah STKIP Muhammadiyah, Kuningan. 5(2), 12-22.

Ermawan, M. T. S. (2018). Analisis Kemampuan Berpikir Intuitif Matematis Siswa dengan Self Efficacy Tinggi. Suska Journal of Mathematics Education, 4(1), 33. https://doi.org/10.24014/sjme.v4i1.4578

Muniri, M. (2018). Peran Berpikir Intuitif dan Analitis dalam Memecahkan Masalah Matematika. Jurnal Tadris Matematika, 1(1), 9-22. https://doi.org/10.21274/jtm.2018.1.1.9-22 
Nazariah, N., Marwan, M., \& Abidin, Z. (2017). Intuisi Siswa SMK dalam Memecahkan Masalah Matematika Ditinjau dari Kemampuan Matematika dan Perbedaan Gender. Jurnal Didaktik Matematika. https://doi.org/10.24815/jdm.v4i1.7561

Sa'o, S. (2016). Berpikir Intuitif Sebagai Solusi. Jurnal Review Pembelajaran Matematika, 1(1), 4356.

Sukmana, A. (2011). Profil berpikir intuitif matematik. Profil Berpikir Intuitif Matematik, 1-55. http://journal.unpar.ac.id/index.php/rekayasa/article/download/105/92

Susilawati, E., Syaf, A. H., \& Susilawati, W. (2017). Pendekatan Eksplorasi Berbasis Intuisi Pada Kemampuan Pemecahan Masalah Matematis. Jurnal Analisa, 3(2), 138-147. https://doi.org/10.15575/ja.v3i2.2015

Usodo, B. (2011). Profil Intuisi Mahasiswa dalam Memecahkan Masalah Matematika Ditinjau Dari Gaya Kognitif Field Dependent da Field Independen. Prosiding Seminar Nasional Matematika Dan Pendidikan Matematika UNS 2011, 95-172.

Usodo, B. (2012). Karakteristik Intuisi Siswa SMA dalam Memecahkan Masalah. Aksioma. 